\title{
Sociological Analysis Of Clean And Healthy Behaviors In Liliriaja Farmers, Soppeng Regency
}

\author{
Latang \\ \{latang@gmail.com $\}$ \\ Universitas Negeri Makassar, Indonesia
}

\begin{abstract}
This study aims to describe the condition of health enviromental and clean and healthy behaviors for farmers who have domestic animals in Jampu village, Liliriaja District, Soppeng Regency. This study is a qualitative research that explains about farming activities and application of a clean and healthy behaviors. This research was carried out in Lonrong, village. Informants were a paddy farmers,garden farmers and have domestic animal which interviewed in depth interviews regarding the procedures for farming and a clean and healthy behaviors. The results showed that farmers were concerned about a clean and healthy environment. Farmers strive to maintain their health because they have daily contact with soil and water which are contaminated with pesticides, herbicides and animal waste that can affect health. Farmer's concern for their health needs to be anticipated by health educators. It can be concluded that farmers need to maintain a healthy and clean environment in work environment as well as living environment so they can lead a clean and healthy life.
\end{abstract}

Keywords: Clean and healthy life, domestic animals, health services

\section{Introduction}

The Human Development Index (HDI) measures the comparison of the three basic dimensions of human development for all countries. These three dimensions are longevity and healthy life, knowledge and decent living standards. Indonesia in 2016 had a HDI of 70.88 . According to WHO, health is a state of well-being that includes physical, mental and social conditions that are not only free from illness or disability. Improving the quality of health in Indonesia is not only the duty of health workers. Support is needed from all aspects of the to build health such as support from economic, social, cultural, political, educational aspects. In addition, individuals awareness to maintain their health also has a very important role. Soppeng Regency is one of the districts in South Sulawesi Province with a population of 225,512 people based on the BPS census in 2013. In 2013, Soppeng Regency had a 73.31 HDI which means it still above than Indonesian HDI rate at 68.40. Many factors support the improvement of Soppeng District HDI, starting from good access of public service such as the presence of services and health workers, schools and teachers, as well as good access to agriculture and trade. However, it is still considered necessary to examine more deeply how the people of Soppeng Regency lived their lives and built their quality of life.

Most villagers in the Soppeng Regency work as farmers and domestic breeders. The people who work as farmers and domestic breeders are people who vulnerable from the various health problems as they encounter in work environment and the lifestyle they live. In such communities, it considered necessary to gain knowledge so they can always maintain their personal and environmental hygiene to avoid diseases and knowledge to always live 
healthy, having good quality life and more productive. The daily activities of farmers in the village are associated with soil. They work in the garden and in the fields, and there are challenges related to physical hygiene during their daily processes. Clearly, the activities involved are a reference for the rapid entry of various disease. For this reason, farmers needs having knowledge to anticipate and protect themselves to stay healthy and clean.

This study in requires a deep understanding of a clean and healthy environment. Furthermore, community knowledge to anticipate diseases that can cause epidemics can make the causes of disease to be eliminated. Farmers get knowledge about maintain health and hygiene behavior, how to avoid diseases from the level of hygiene and healthy lifestyles and knowledge in using of herbal medicines with appropriate dosage.

In line with this assumption, it is necessary for the farming community to apply a healthy and clean lifestyle that contributes to them and can increase their productivity as farmers to lead a prosperous life. Healthy, clean and prosperous lifestyle are hoping to be carried out optimally.

\section{Literature Review}

\subsection{Conditions and Changes in Society}

The condition of the farmers will be reviewed from health aspect, it will be studied on the importance of understanding and thinking about health and the environment. The process for maintaining health requires a deep understanding of healthy living procedures. It is clear that farmers really need an understanding how to live clean and healthy, because farmers are engaged in activities in the fields and garden. Moreover, farmers have a dual activity in raising livestock, that make farmers really need an understanding of cleanliness.

\subsection{Environmental Health}

The scope of environmental health and environmental control efforts described by Maulana, (2014) include: 1) providing adequate clean water and fulfill health requirements, 2) food and beverages produced on a large scale and widely consumed by the community, 3) air pollution due to forest combustion, 3) liquid and solid waste originating from households, agriculture and livestock, 4) control of arthropoda and rodents which become vectors and how to break the chain of disease transmission, 5) livable house and buildings and fulfills health requirements , 6) noise and radiation and occupational health, 8) sanitation surveys for planning, monitoring and evaluating environmental health programs. It is observed that knowledge of health is needed which is related to the application of healthy and clean living in the environment so that the farming community can live a healthy and happy life. Understanding of the eight points above can provide a reference to a healthy way of life, especially environmental health in the form of a living environment. Besides that, point 5-8 is an environmental problem for urban people, but this problem can also be found in rural areas, especially if there are industries.

\subsection{Knowledge of Public Health}

Maulana (2014) outlines the health problems that need to be sought: 1) prevention efforts; preventive effort is an attempt by an individual to prevent something unwanted. For that efforts that need to be done are: a) regular health checks, b) provision of vitamin A, through posyandu, puskesmas, or at home, c) pregnancy examination, d) early detection of cases and 
risk factors, e) immunization for babies and pregnant women. The treatment effort (curative) needs to be done as follows: a) support healing, care, b) care of sick people as a follow-up, c) administration of drugs. While rehabilitation efforts include: a) physical exercise for those who experience physical disorders such as fractures, b) physical exercise for people with certain diseases such as breathing exercises. Benih, 2014 stated that the health body or physical health;were the most real health dimensions tha and have a important role in the mechanistic function of the body. Bodies health can be obtained by maintaining cleanliness, healthy food, a regular way of life, increasing endurance and avoiding the occurrence of diseases in our body. Another important thing that can support the health of the body is to provide houses with facilities for healthy living, such as the availability of clean water sources, the presence of garbage or waste disposal, the existence of adequate toilets, and the existence of first aid kits to deal with sudden accidents at home. After all, health checkups, self-examination is needed even though our bodies are not sick or healthy.

\subsection{Social Health}

Health sociology is categorized as a branch of art from sociology that is relatively new. According to Straus (in Maulana, 2014), health sociology is divided into 2, namely between medical field sociology and sociology in the medical field. Medical field sociology consists of sociological studies of factors in the medical field carried out by sociologists who occupy independent positions outside the field and aim to develop sociology and to test sociological principles and theories. Whereas, sociology in the medical field is a joint research and teaching which often involves the integration of concepts, techniques, and personnel from various disciplines and sociology used as a complement to the medical field.

\subsection{Clean and Healthy Life Behavior}

RI Ministry of Health (2014) argues that Clean and Healthy Behavior (PHBS) is all behavior carried out on own awareness to help oneself, family and society to maintain, protect and improve health. According to Becker in (Benih A. 2014) explains the behavior of life that: 1) eat with a balanced menu, a balanced menu means the quality of nutrients needed by the body, 2) regular exercise, which also includes quality (movement) and quality in the sense frequency and time used for exercise, 3) not smoking, smoking is an ugly habit that results in various diseases, 4) not drinking liquor and drugs, drinking habits and consuming drugs and other dangerous, 5) adequate rest, 6) controlling stress, 7) other behaviors or lifestyles that are positive for health.

Benih A (2014) added that knowledge about health includes what someone knows about how to maintain health. A healthy attitude towards health begins with yourself. Health practices for healthy living are all activities or activities of people in order to maintain health.

\subsection{Farmers}

In general, farmers are defined as people who work in the agricultural sector and most of their income comes from the agricultural sector. Within the limits of statistics, people who work in the agricultural sector at least one hour a week, can be called farmers. In addition, people who live in the countryside and are psychologically farmers, are often referred to as farmers. 


\section{Research Methods}

The approach taken in this study is a qualitative approach that describes the level of quality of knowledge and clean and healthy behavior for farmers in Liliriaja Subdistrict, Soppeng District. Based on this type of research, it is descriptive study that aims to provide a systematic, factual and accurate description of the conditions of clean and healthy behavior in Liliriaja, Soppeng Regency. There are two aspects that will be assessed in this study. The clean and healthy behavior in individuals and conditions of clean and healthy living behavior in community life.

Individual hygiene and health are assessed by reviewing individual behavior to maintain hygiene, physically and mentally healthy. The behavior consists of washing hands, brushing teeth, bathing, good and correct bowel habits, exercise habits, types and diet patterns, rest patterns, smoking habits, ability to control emotions, the quality of social relationships in individuals and how individual behavior in seeking and obtaining services from health facilities.

In aspects of community life, clean and healthy behavior is assessed on the ability of the community to maintain environmental cleanliness, good and correct waste management, environmental sanitation, the presence of the community in promotive and preventive activities carried out by health service facilities, right water and waste management.

This research was conducted in Jampu Village, Liliriaja District, Soppeng Regency and will last for 6 months from December 1, 2017 to May 1, 2018. The location of this research be done with the conditions of the people who mostly have regular jobs as farmers. Of course this is very appropriate to trace the level of cleanliness and public health. The research location is affordable where the location is near the capital city of Soppeng Regency.

The subjects of this study were farmers who worked in rice fields and in gardens and farmers who owned stock (domestic). The number of research subjects is 10 informants. From the 10 informants of this study there were several informants who had multiple jobs, as a paddy farmers, gardens and domestic farmers.

The data are obtained through an interview process using a list of systematically arranged questions. Questions are based on matters relating to farmer's knowledge and behavior towards clean and healthy living. Questions consist of closed or open questions. In addition, the researchers conducted observations with the aim of directly observing the behavior of the community related to clean and healthy life.

The method of selecting samples or informants for farmers to be studied will be done purposively from the farmer population in Jampu Village, Liliriaja District, Soppeng Regency. The number of informants to be studied will be selected based on the number of informants included in the research criteria.

Data from research results in the form of interviews and observations will be input into the data. The data is processed and analyzed using a data collection program. The results of processing data from the informant will then be interpreted into conclusions or research results. While the data obtained from in-depth interviews will be reduced, verified and interpreted to draw conclusions. 


\section{Results And Discussion}

\subsection{Informant 1.}

A farmer named PU who was in the village of Jampu who worked as a farmer for 22 years. In his daily activities he tries to farm the garden and raise cattle in addition to other jobs. He added that his habit of raising cows and storing cows under the column of his house was because his cow was guarded to avoid snealing. The farming activities are pursued according to their ability to cultivate. He always learns to add experience based on social learning or social learning. Learning efforts are related to competencies about intensification of agriculture.

Puddin has garden farming activities, besides that he is very concerned about the technique of protecting himself from diseases by maintaining his health. He works according to a free working time arrangement. He explains about a healthy lifestyle based on habits to keep himself from living a healthy life. Habits that are carried out to maintain a healthy life are: clean clothes, bathing with bath soap, and eating breakfast before working in the garden.

Regarding of the enviromental health, he explained that: environmental hygiene is maintained with every day cleaning the column of his house, in the bathroom a simple toilet is provided, household waste is disposed of in the trash. In addition, he paid attention to his health with the habit of going to the puskesmas for treatment. The drugs commonly consumed are simple drugs or generic drugs.

\subsection{Informant 2.}

MA is a farmer who is in Lonrong, Jampu village. Every day, he works in the fields, gardens. In addition, he tried to maintain horses to be used to lift garden produce in the form of coconuts, bananas. He used horses to transport the rice fields (grain) and specifically the horses were kept to be used to try farming such as plowing fields. MA tried to farm for around 40 years. His experience of farming is through the process of social learning. He often followed the guidance of agricultural instructors. In addition, he can compare and match his experience with the new knowledge he acquired. Judging from his daily activities as farmer, he also considered the level of health. He took care of himself from illness, especially in terms of health and environmental cleanliness, because he kept horses and even kept his horse not far from his house. As for his health, he understands about environmental cleanliness because horses are stored not far from home. Horse waste can affect health, especially diseases caused by horse feces can be dangerous. Tetanus needs to be anticipated where the main cause is horse feces. MA can protect herself from high-risk diseases, and was given direction so he can realize the impact of environmental hygiene.

\subsection{Informant 3 .}

SYR, about 52 years old, in the village of Jampu said that he had been farming for more than 22 years. He cultivated rice fields, besides that he cultivated cocoa plantations and he kept horse. He explained that his daily activities were in the land to be processed to the maximum, and he was engaged in this activity to fulfill his life needs.

SYR explained that his physical condition had begun to decline, even he said that the physical condition had begun to feel pain, especially ulcer disease. Therefore, he was very concerned about breakfast before going to his rice fields. Regarding physical cleanliness and clothes always cleaned after returning from work, and clothes at home are always kept clean. 
He added that the cleanliness of the home environment is always maintained, especially the cleanliness of the toilet that suitable to use, clean water, and for the needs of drinking water is always cooked. He said about his clothes not always being ironed but the level of cleanliness was kept as optimal as possible. Whereas to keep his health, he drinks non-alcoholic drinks.

He further explained that he felt there was a physical abnormality that was felt so he tried to take generic drugs or market drugs. He also explained that he often had toothache. Of course this, he is often bothered to rest.

He informed him that he rarely went to the hospital, but he was very concerned about his health, if health workers came to visit for community service. Specifically, it was stated that he sometimes felt disturbed by sleep when there were small problems, but it was rather difficult to avoid but tried to solve it.

\subsection{Informant 4.}

ASM is a farmer who takes his daily activities seriously. He tried to pay attention to his environmental conditions and he even noticed about the climate. He always cultivates multicrops on his land in the form of horticulture plants such as beans, vegetables and other plants. On his plantation, he planted long-term crops in the form of breadfruit and banana. His success in farming was considered a success because he was able to send his children to level of magistrate.

He tried farming which was adjusted to his discipline in managing time, because he was among the community leaders who at all times served the needs of the people around him. Her concern is about the people who serve her at all times. He cares about citizens, he cares about the environment, he cares about his health.

ASM operates around 28 years. He works diligently and is able to organize daily activities regarding when to be in the garden, rice fields, and community services. He pays attention to his health and environmental hygiene, especially regarding the home environment is very concerned. Specifically regarding his physical health, he always had breakfast, dressed in simple but clean. He also said that he took a shower first and then had lunch. He was also very obedient in the implementation of his regular worship, even he also set the time for rest. Even though he realized that he had also been sick and he tried to get treatment and go to the hospital. He said that he was often served by health care officers for health checks.

Environmental health is well maintained which is mainly the cleanliness of toilets, bathrooms and others around his house. Disposal of dirt, garbage, even drinking water is maintained. The discipline to maintain physical and environmental cleanliness is part of life because he thinks that cleanliness is a part of faith.

Examining from the information above can be underlined that maintaining health, healthy food and regular way of life are hopes to be able to live by increasing endurance and avoiding the occurrence of disease. For this reason, it is observed from the farmer's procedures for cleanliness, clean food and eating patterns, sleep and rest that needs to be applied in the continuity of a healthy and clean life.

\subsection{Informant 5.}

YSR was born in 1969 in Jampu Village, Liliriaja District, Soppeng Regency. In addition to his work as a rice farmer, he maintains cattle as an activity to increase income. About 10 years he kept cows always kept behind his house. His daily activities was find grass as food for livestock while paddy fields are filled with rice. If during the harvest season, he releases his cow in the rice fields. 
He has kept cattle for about ten years. He only raises about 3 cows. If it's too much, he can't take care of it because he also works in the fields as a rice farmer. The raised cow will be sold if it is estimated to have benefited.

YSR said that the cleanliness of the environment around the cattle shed was maintained so as not to cause a smell. He said that cow dung was placed in a dump site far from home. However, he saved the waste for preparation of manure.

He explained that the cleanliness of the environment and the cleanliness of himself were maintained. He takes care of and makes disposal of cow dung, so that cow dung is dumped in a special place behind his house. It was also added that the habits carried out specifically for self-pity to stay healthy and clean.

YSR has good attention to the health of himself and his family. He and his family maintain the cleanliness of the environment by structuring the front environment of a beautiful house besides being planted with ornamental plants and preserved by its beauty. This means attention to beauty shows cleanliness and neatness. About his daily habits if he feels sick, he quickly goes to the puskesmas to monitor his health.

YSR familiarizes himself with the puskesmas for treatment and health care. Besides, he also uses herbal medicines or using plant if only he felt unwell. Regarding toothache, it was felt because of that, he diligently used tooth paste when he brushed his teeth and showered using bath soap.

Looking at the health level of this family is rather susceptible to disease. If it is traced to its work as a farmer and maintains domestic livestock, the level of cleanliness of itself remains well maintained. With the ability to maintain cleanliness, eat healthy and nutritious food and a regular way of life so that he can survive the disease.

\subsection{Informant 6.}

RSD has a job as a rice farmer and goat farmer. He cultivated farming for approximately 20 years. He was born in Jampu Village, Liliriaja District, Soppeng Regency. His daily activities are looking for grass that are worthy of being eaten by his goat. He started a business of raising goats around 10 years. The business of raising goats is quite successful. He was able to send his children to high school.

RSD works regularly, especially he get to take care of goat food. After the goat's food is ready, he tries to monitor the rice fields that are not far from the house. This activity is carried out to increase income. He also has sidework and also as a community leader who took care of activities in the village. He has a job as chairman of the BPD in the village. So it's an attempt to design village programs along with village head. In addition, he actively delivered village development programs. Especially the village development program is mainly considered about the community living a healthy, clean and prosperous life. Regarding public health, he is very concerned about improving people's quality of life.

To improve the health of rural communities, it is programmed that posyandu for adults can monitor the health of residents. This is evident near the house where the posyandu is located. Rusdi pays attention to community interaction activities and village community development programs. He conveyed to the community a clean and healthy lifestyle.

RSD pays attention to environmental hygiene especially because he cares for goat animals. Of course it really needs attention to environmental cleanliness, so he always takes care of the goat manure that he kept. He conveyed his experience about the contamination of well water caused by paddy farmers washing farm equipment that was not quite right so causing diarrhea for big community. He stated that condition to health workers to make visit for inspect contaminated wells with pesticide eradication drugs. 
Then he and his family pay attention to the cleanliness around the house, especially he cleans the toilet, and he looks at the garbage disposal which is more specifically the garbage from the wooden branches arranged from the food of the goats.

\subsection{Informant 7.}

KLD is one of the rice farmers, gardens and cattle keepers and horses. He makes every effort to maintain cattle for preparation every year can be sold. He keeps cows for about 10 years. He did maintenance of cattle as an income enhancer. He focuses on farming which is focused every day on preparing cows and horse food. Whereas horses that are kept can help to transport rice production and other production from the garden.

KLD kept livestock behind his house on the grounds that he could monitor livestock and he was worried if the cattle were kept away from the house. But he noticed about the cleanliness of livestock manure.

KLD added that the activities carried out in the farming business were carried out and his work as a farmer was carried out according to his abilities. But attention to a healthy lifestyle will be considered. He noticed about the cleanliness of himself after returning from his job. He also understood about the disease so he tried to go to the puskesmas if he felt there was a disruption to his health. He said that the disease he often experienced was toothache. This is because the attention to dental health is not cared for because activities in the garden still can be carried out according to the ability and food from fruits from the garden is consumed irregularly.

Regarding the cleanliness of the environment around his house it was considered unhealthy, where cow manure and horses were stored so that the horse's sapid stung was stinging. For him personally does not feel the smell. The possibility of this is affected because of the frequency of experience so that it is considered normal.

Concern about environmental hygiene is not in accordance with health measures. However, for him it was considered normal. It is clear that he is more concerned with the direct benefits of animals. It was explained about cow dung and horses collected to be used as manure.

Observed from the facts above, it can be appreciated that the concern for the level of health is very important. For this reason, the health office must visit the village to disseminate important clean and healthy lifestyle. Clearly this case is directed to find the best solution that does not harm farmers and farmers can receive direct benefits about health. The technique for delivering health information that is wisely carried out optimally.

Based on the description of the results of this study, we will discuss the environmental health conditions of farmers in the village of Jampu, Liliriaja District, Soppeng Regency. The findings obtained were the conditions of farmers who became informants in this study explaining that their activities in daily life contained conditions that could provide encouragement to maintain their health.

\section{Discussion}

Conditions in farmer's daily activities are conditions that allow infectious diseases such as diarrhea caused by hygiene conditions. But farmers in the village of Jampu, Liliriaja District can find out about the condition of clean and healthy water. For this reason, farmers can pay attention to the cleanliness of their environment. In line with the clean and healthy environment, it was understood earlier about the importance of protecting the environment. 
Environmental health is maintained optimally by farmers. Farmers pay attention to their environment, especially the environment around the house is noticed because livestock are kept around their homes. For this reason, farmers will maintain their livestock continuously. This is very closely related to the cleanliness of a clean and healthy environment, so farmers strive to maintain a clean and healthy environment.

Environmental health conditions are one of the drivers to be able to sustain life more survive. The ability of farmers to survive can survive a clean and healthy environment. It is clear that farmers are trying to adapt to their environment, so that they can carry out their main activities as farmers to be able to fulfill their needs and prosperous lives.

Clean and healthy environmental health conditions are hopes to be maintained about public health specifically for farmers in the village of Jampu, Liliriaja District, Soppeng Regency. A clean and healthy environment is the main foundation for carrying out basic tasks as a farmer.

Furthermore, it was added about the level of farmer's knowledge of clean and healthy living, where farmers understand a clean and healthy lifestyle. Farmers obtain knowledge about clean and healthy life from health services workers. Information about health is obtained directly or indirectly from health educators.

Direct information about health is that farmers try to find knowledge about ways to manage pesticide tools and prevent them so that farmers stay healthy. Whereas indirectly the knowledge of the farmer is that health care officers come to the village to convey health information specifically regarding the procedures for preventing disease and more specifically about diseases that can be endemic. Knowledge about the disease is given by health educators who are programmed.

The degree of long living, healthy and clean is the hope of the farmers to continue the activities of fulfilling the necessities of life. This expectation can be realized if the farmers carry out and pay attention in accordance with the instructions of the health care provider or field instructor in the health sector. The process of socializing field workers in the health sector will have a positive impact on the standard of living of farmers who live clean and healthy lives.

With regard to the above description, the efforts made to overcome the health problems of farmers, namely: 1) conducting farming activities that are in accordance with health conditions, 2) paying attention to the arrangements for working, resting, and other activities related to social activities, 3) understand about diseases that are less environmentally affected or polluted environment, 4) understand about diseases that have an impact on epidemics, 5) anticipate high risk disease as soon as possible and try as soon as possible to go to the hospital.

Dissemination of health information carried out by farmers is done both face to face, also farmers can pay attention to the use of information technology. So farmers are no longer left behind with information, but farmers are able to disseminate information relating to a clean and healthy lifestyle. This is observed that the ability of farmers to receive information about health. Farmers are able to filter information to analyze according to their level of education.

\section{Conclusions And Recommendations}

It can be concluded that farmers can pay attention to a clean and healthy lifestyle. Farmers are aware of the importance of a clean and healthy environment. Farmers are able to take good care of themselves about personal hygiene, environmental preservation, manage themselves to stay clean and healthy, receiving information about health from health 
educators, trying to visit hospitals to receive health services when their physical conditions have health problems. Farmers pay attention to health services through BPJS and KIS.

In connection with the conclusions in this study, it can be suggested that:

1. Farmers strive to improve their health by paying attention to environmental health in order to stay healthy and clean

2. Farmers are willing to keep the environment around the house clean and healthy

3. Farmers receive health information from health educators

4. Farmers and health educators together can disseminate the importance of environmental health

\section{Daftar Pustaka}

[1] Anwas. Oos M. 2014 Pemberdayaan Masyarakat di Era Global. Bandung: Alfabeta.

[2] Benih, Ade. 2014 Sosiologi Kesehatan. Yogyakarta: Numed.

[3] Hafsara. H.R. 2016. Penguatan Upaya Kesehatan Masyarakat, dan Pemberdayaan Masyarakat Bidang Kesehatan di Indonesia. Yokyakarta: Gajah Mada University Press.

[4] Maulana, Nova. 2014 Buku Ajar Sosiologi dan Antropologi Kesehatan. Yogyakarta: Numed.

[5] Eka Pratiwi, Prita. 2015. Perilaku Hidup Bersih dan Sehat (PHBS) pada Tatanan Rumah Tangga Masyarakat Using. Jember: Universitas Jember.

[6] Sulistyowati, Lily S. 2015. 10 Pesan Hidup Sehat dalam Kedaruratan. Jakarta: Kemenkes RI \& Unicef.

[7]http://repository.usu.ac.id/bitstream/handle/123456789/62471/Chapter\%20II.pdf?sequence $\equiv 4$ \&isAllowed $=\mathrm{y}$ 